\title{
Path Coefficient Analysis of Growth and Yield Traits of Rice (Oryza sativa L.) at Bokolori, Talata Mafara, Sudan Savanna Ecological Zone, Nigeria
}

\author{
ALHASSAN, J; *MUSA, M \\ Department of Crop Science, Usmanu Danfodiyo University, P.M.B. 2346, Sokoto, Nigeria \\ *Corresponding Author Email: jazulina@yahoo.com; Tel: 08065818939
}

\begin{abstract}
In order to determine the direct and indirect effects of yield and yield components of rice, a field experiment was conducted in each of the wet seasons of 2016 and 2017 at Irrigation Research Stations of the Institute for Agricultural Research, Bokolori, Talata Mafara, in the Sudan Savanna ecological zone of Nigeria $\left(12^{\circ} 34^{\prime}\right.$ N; $\left.06^{\circ} 04^{\prime} \mathrm{E}\right)$. The treatment consisted of four (4) weed management practice (Oxadiazon at $1.0 \mathrm{~kg}$ a.i ha ${ }^{-1}$ [pre-emergence], Orizo-plus [proponil $360 \mathrm{~g} / \mathrm{l}+2,4-\mathrm{D} 200 \mathrm{~g} / \mathrm{l}$ ] at $2.8 \mathrm{~kg}$ a.i ha ${ }^{-1}$ [post emergence at $3 \mathrm{WAS}$ ], manual weeding [at 3 and $6 \mathrm{WAS}$ ] and weedy check [control]); three (3) each of seeding method (Drilling, Dibbling and Broadcast) and seed rate (40 kg ha ${ }^{-1} ; 70$ $\left.\mathrm{kg} \mathrm{ha}^{-1} ; 100 \mathrm{~kg} \mathrm{ha}^{-1}\right)$. The experiment was laid in a split plot design replicated three times. Weed management practice was assigned to the main plots while the combination of seeding method and seed rate to the subplots. Data were collected on plant height, leaf area, crop dry matter, tillering ability, crop growth rate, harvest index (HI), panicle length, number of grains per panicle, 1000-grain weight and paddy yield. The result indicated that, the highest individual contribution of $25.04 \%$ to paddy yield was made by dry matter followed by 1000 -grain weight $(8.74 \%)$, tillering ability ( $8.46 \%)$, leaf area (3.13\%), number of grains per panicle $(1.03 \%)$ and the least was from panicle length $(0.83 \%)$. The contribution of these growth and yield attributes to yield suggests that, priority be given to these traits when making selection for improvement.
\end{abstract}

\section{DOI: https://dx.doi.org/10.4314/jasem.v25i7.33}

Copyright: Copyright $\odot 2021$ Alhassan and Musa. This is an open access article distributed under the Creative Commons Attribution License (CCL), which permits unrestricted use, distribution, and reproduction in any medium, provided the original work is properly cited.

Dates: Received: 10 May 2021; Revised: 28 June 2021; Accepted: 01 July 2021

Keywords: Path analysis, Oryza sativa, Growth components, Yield components, Sudan savanna

Rice (Oryza sativa L.) is one of the most important food grain that constitutes a dominant portion of a world standard diet. Despite its position among the highly rated cereal crops, the geometric growth rate of the global population has called for improving the current yield for this extremely important cereal. The genus, to which it belongs, Oryza, contains 25 species, only two of which are referred to as cultivated rice: Oryza sativa sown in South-East Asian, and Oryza glaberrima in West Africa (Singh et al., 2015). Rice is the staple food of $60 \%$ of China's population and more than $50 \%$ of the global population. Compared with the average global rice production of $4.3 \mathrm{tha}^{-1}$, the average yield of rice in Nigeria is $4.8 \mathrm{tha}^{-1}$ while, the average yield of rice in the 30 million hectares of China is 6.8 $\mathrm{t} \mathrm{ha}^{-1}$ (FAOSTAT, 2018). However, the increasing frequency of temperature extremes, onset of droughts, storms and floods, a rapidly growing population and urbanization are still major constraints against ensuring food security (Foley et al., 2011; Ray et al., 2012; Qian et al., 2016; Zeng et al., 2017). Therefore, it is essential to develop high-yielding, climateresilient and high-quality rice varieties. The measurement of the association of characters with yield and among themselves is very much essential for improvement of yield and its components. Therefore, the knowledge of association of component characters with yield has great importance to plant breeders, as it helps in their selection with more precision and accuracy (Venu et al., 2011; Zeng et al., 2017). The correlation studies simply measure the association between yield and other traits, while as path coefficient analysis permits the separation of coefficient into direct effects (path coefficient) and indirect effects (effect exerted through other variables). It is a standardized partial regression analysis and deals with a closed system of variable that are linearly related. Such information provides for realistic basis of allocation of appropriate weightage to various yield components (Iqbal et al., 2006). Path analysis will indicate whether the association of the yield related traits with yield is due to their direct effect on yield (true association and selection can be made for improvement), or is a consequence of their indirect effect via some other traits (s) and in such cases geneticist has to select the trait through which the indirect effect has been exerted. Study by Iqbal et al. (2003) reported that path analysis of direct and indirect effect 
estimates vary for different traits with variation in genetic material. Hence, path analysis of direct and indirect effect estimation would provide useful information for planning a successful breeding programme.

\section{MATERIALS AND METHODS}

Two field trials were conducted in each of the wet seasons of 2016 and 2017 at Irrigation Research Stations of the Institute for Agricultural Research located at Bakolori Irrigation Scheme Talata Mafara, in the Sudan Savanna ecological zone of Nigeria. The treatments consisted of three (3) each of seeding method (Drilling, Dibbling and Broadcast) and seed rate (40 kg ha ${ }^{-1} ; 70 \mathrm{~kg} \mathrm{ha}^{-1} ; 100 \mathrm{~kg} \mathrm{ha}^{-1}$ ) and four (4) weed management practice (Oxadiazon at $1.0 \mathrm{~kg}$ a.i $\mathrm{ha}^{-1}$ [pre-emergence], Orizo-plus [proponil $360 \mathrm{~g} / \mathrm{l}+$ 2,4-D $200 \mathrm{~g} / \mathrm{l}$ ] at $2.8 \mathrm{~kg}$ a.i $\mathrm{ha}^{-1}$ [post emergence at 3 WAS], manual weeding [at 3 and 6 WAS] and weedy check [control]). The experiment was laid in a split plot design replicated three times. Weed management practice was assigned to the main plots while the combination of seeding method and seed rate to the subplots. SIPI-602033 (FARO 44) was used for the experiment. The seed was sown on rows, $20 \mathrm{~cm}$ apart in both drilled and dibbled plots and at $20 \mathrm{~cm}$ between stands in dibbled plots. Inorganic fertilizer was applied in slit dose by broadcast at the rate of $120 \mathrm{~kg} \mathrm{ha}^{-1} \mathrm{~N}$; $60 \mathrm{~kg} \mathrm{ha}^{-1} \mathrm{P}_{2} \mathrm{O}_{5} ; 60 \mathrm{~kg} \mathrm{ha}^{-1} \mathrm{~K}_{2} \mathrm{O}$.
Data were collected on plant height, leaf area, crop dry matter, tillering ability, crop growth rate, harvest index (HI), Panicle length, number of grains per panicle, 1000-grain weight and paddy yield. Data collected from the observations were subjected to analysis of variance. The direct and indirect effects of individual and combined contributions of some selected characters to paddy yield were determined using path coefficient analysis as described by Dewey and Lu (1959).

\section{RESULTS AND DISCUSSION}

Path coefficient and percent contribution: The path analysis showed the contribution of some rice growth and yield components with paddy yield at Talata Mafara in 2016, 2017 and mean as presented in Table 1.The result in 2016 indicated that dry matter contributed most $(21.32 \%)$ to paddy yield, followed by grain weight $(14.28 \%)$, tillering ability $(3.76 \%)$, leaf area $(3.53 \%)$, grains per panicle $(3.11 \%)$ and panicle length $(0.16 \%)$. The highest contribution of two characters to paddy yield ha ${ }^{-1}$ of $15.50 \%$ was from dry matter and 1000-grain weight, also combined contribution of dry matter and tillering ability to paddy yield was $10.89 \%$. However, the percent combined contributions of leaf area and tillering ability, panicle length, and 1000-grain weight to paddy yield were negative.

Table 1: Percentage contribution of growth and yield attributes of rice to paddy yield in 2016, 2017 and mean data at Talata Mafara

\begin{tabular}{llll}
\hline Parameter & \multicolumn{3}{l}{ Percent contribution (\%) } \\
\hline Individual contribution & $\mathbf{2 0 1 6}$ & $\mathbf{2 0 1 7}$ & Mean \\
\hline Dry matter & 21.32 & 29.94 & 25.04 \\
Leaf area & 3.11 & 3.53 & 3.13 \\
Tillering ability & 3.76 & 14.28 & 8.46 \\
Panicle length & 0.16 & 1.01 & 0.83 \\
Number of grains per panicle & 1.31 & 1.48 & 1.03 \\
1000-grain weight & 14.28 & 3.20 & 8.74 \\
Combined contribution & & & \\
Dry matter via leaf area & 8.71 & 7.09 & 8.82 \\
Dry matter via tillering ability & 10.89 & 5.02 & 8.84 \\
Dry matter via panicle length & 0.79 & 0.15 & 0.46 \\
Dry matter via number of grains per panicle & 6.23 & 4.93 & 5.56 \\
Dry matter via 1000-grain weight & 15.50 & 10.65 & 13.04 \\
Leaf area via tillering ability & -0.59 & -0.95 & -0.77 \\
Leaf area via panicle length & -0.04 & -0.12 & 0.11 \\
Leaf area via number of grains per panicle & -0.37 & -0.82 & -0.48 \\
Leaf area via 1000-grain weight & -0.75 & -1.16 & -0.92 \\
Tillering ability via panicle length & 0.07 & 0.09 & 0.08 \\
Tillering ability via number of grains per panicle & 2.13 & 2.71 & 2.92 \\
Tillering ability via 1000-grain weight & 4.26 & 6.02 & 5.14 \\
Panicle length via number of grains per panicle & 0.03 & 0.01 & 0.02 \\
Panicle length via 1000-grain weight & 1.35 & 1.06 & 1.21 \\
Number of grains per panicle via 1000-grain weight & 1.66 & 1.89 & 1.78 \\
Residual & 10.71 & 12.05 & 11.38 \\
Total & 100.00 & 100.00 & 100.00 \\
\hline
\end{tabular}

The percent contribution unaccounted was $10.71 \%$. In 2017, the individual percent contribution of $29.94 \%$, $14.28 \%, 3.53 \%, 3.20 \%$ and $1.47 \%$ was made from dry matter, tillering ability, leaf area, 1000-grain weight and number of grains per panicle respectively. The combined percent contribution of dry matter and 1000- 
grain weight was the highest combined percent contribution of $10.65 \%$ to yield while the least was obtained from combined percent contribution of leaf area and tillering ability $(-0.95 \%)$ that was negative. The percent unaccounted variability was $12.05 \%$. The mean data indicated that the highest individual contribution of $25.04 \%$ to paddy yield was made by dry matter followed by that from 1000 -grain weight $(8.74 \%)$, tillering ability $(8.46 \%)$, leaf area $(3.13 \%)$, number of grains per panicle $(1.03 \%)$ and the least was from panicle length $(0.83 \%)$. The combined contribution of dry matter and 1000-grain weight $(13.04 \%)$ was the highest while the combined contributions of leaf area and 1000-grain weight $(0.01 \%)$ was the least. The percent contribution that could not otherwise be explained was $11.38 \%$.

Direct and indirect effect of growth and yield attributes of rice: The direct and indirect effect of different growth and yield components on paddy yield $\mathrm{t} \mathrm{ha}^{-1}$ in 2016 and 2017 wet seasons is presented in Table 2. The greatest positive direct contribution to yield was from dry matter per plant $(0.6271)$ followed by 1000-grain weight (0.3780), tillering ability (0.1940) and number of grains per panicle (0.1148) while the least positive contribution to paddy yield was from panicle length $(0.0122)$ while the negative direct effect was obtained from leaf area (-0.0340). The highest positive indirect effect was from dry matter via leaf area plant ${ }^{-1}(0.5462)$, followed by dry matter via panicle length $(0.3248)$. The least positive indirect effect to yield was through tillering ability via panicle length (0.0017). All the indirect effect through the leaf area was found to be negative. In 2017, the dry matter plant ${ }^{-1}$ had the highest direct effect to yield (0.6160), followed by tillering ability $(0.3780)$ and 1000 -grain weight $(0.1790)$ while leaf area had the least direct effect on yield (-0.0732). The highest indirect effect on yield was through dry matter via leaf area (0.4848). However all the indirect effect of leaf area were negative. In the mean data, the highest direct effect of 0.6168 was produced by dry matter while the least was found to be leaf area (-0.077). The highest indirect effect of 0.2770 was accounted by dry matter via 1000-grain weight while the lowest mean percent contribution was on leaf area via 1000-grain weight. Complete knowledge on interrelationship of plant character like paddy yield with other characters is of paramount importance to breeders in making decisions for improvement in complex quantitative character like paddy yield for which direct selection is not much effective. The positive and significant association between paddy yield and growth and yield attributes suggests that, priority be given to these traits when making selection for improvement. Crop dry matter exhibited maximum positive direct effect on paddy yield followed by 1000-grain weight, panicle length and tillering ability.

Table 2: The direct and indirect contribution of growth and yield components to paddy yield of rice in 2016,2017 and mean data at Talata Mafara

\begin{tabular}{|c|c|c|c|c|c|c|c|}
\hline \multirow[b]{2}{*}{ Yield attributes } & \multicolumn{7}{|c|}{ Effect through } \\
\hline & $\begin{array}{l}\text { Dry } \\
\text { matter }\end{array}$ & $\begin{array}{l}\text { Leaf } \\
\text { area }\end{array}$ & $\begin{array}{l}\text { Tillering } \\
\text { ability }\end{array}$ & $\begin{array}{l}\text { Panicle } \\
\text { length }\end{array}$ & $\begin{array}{l}\text { No. of } \\
\text { grains/ } \\
\text { panicle }\end{array}$ & $\begin{array}{l}1000 \\
\text { grain } \\
\text { weight }\end{array}$ & $\begin{array}{c}\text { Total } \\
\text { correlated }\end{array}$ \\
\hline \multicolumn{8}{|c|}{2016} \\
\hline Dry matter & 0.6271 & -0.0296 & 0.0869 & 0.0063 & 0.0497 & 0.1236 & 0.8640 \\
\hline Leaf area & 0.5462 & -0.0340 & 0.0869 & 0.0063 & 0.0557 & 0.1100 & 0.7710 \\
\hline Tillering ability & 0.2809 & -0.0252 & 0.1940 & 0.0017 & 0.0291 & 0.1036 & 0.5940 \\
\hline Panicle length & 0.3248 & -0.0174 & 0.0275 & 0.0122 & 0.0140 & 0.1448 & 0.5060 \\
\hline No. of grains/panicle & 0.2715 & -0.0165 & 0.0491 & 0.0015 & 0.1148 & 0.0726 & 0.4930 \\
\hline 1000-grain weight & 0.2051 & -0.3399 & 0.0531 & 0.0047 & 0.0220 & 0.3780 & 0.6530 \\
\hline \multicolumn{8}{|c|}{2017} \\
\hline Dry matter & 0.6160 & -0.0576 & 0.0408 & 0.0012 & 0.0401 & 0.0865 & 0.7270 \\
\hline Leaf area & 0.4848 & -0.0732 & 0.0650 & 0.0015 & 0.0562 & 0.0797 & 0.6140 \\
\hline Tillering ability & 0.0665 & -0.0126 & 0.3780 & 0.0011 & 0.0358 & 0.0551 & 0.5240 \\
\hline Panicle length & 0.2556 & -0.0382 & 0.1451 & 0.0029 & 0.0156 & 0.0999 & 0.4810 \\
\hline No. of grains/panicle & 0.2027 & -0.0337 & 0.1111 & 0.0004 & 0.1219 & 0.0367 & 0.4390 \\
\hline 1000-grain weight & 0.2975 & -0.0326 & 0.1164 & 0.0016 & 0.0250 & 0.1790 & 0.5870 \\
\hline \multicolumn{8}{|c|}{ Mean } \\
\hline Dry matter & 0.6168 & 0.0715 & 0.0231 & 0.0346 & -0.0021 & 0.1081 & 0.8520 \\
\hline Leaf area & 0.2492 & -0.0770 & 0.0113 & 0.1161 & -0.0138 & -0.1279 & 0.1579 \\
\hline Tillering ability & 0.2085 & 0.0294 & 0.0683 & 0.0388 & -0.0023 & 0.0503 & 0.3930 \\
\hline Panicle length & 0.1326 & 0.1278 & 0.0165 & 0.1609 & -0.0032 & 0.0544 & 0.4890 \\
\hline No. of grains/panicle & 0.0728 & 0.1350 & 0.0086 & 0.0282 & 0.1180 & 0.0995 & 0.4260 \\
\hline 1000-grain weight & 0.2770 & -0.0940 & 0.0143 & 0.0364 & -0.0075 & 0.2408 & 0.4670 \\
\hline
\end{tabular}


Positive direct effects of these traits on paddy yield indicated their importance in determining this complex character and therefore, should be kept in mind while practicing selection aimed at improving paddy yield. Similar results were also reported by Jayasudha and Sharma (2010) and Zulqarnain et al. (2012) on number of tillers per plant and filled grains per panicle. Leaf area expressed negative direct effect on paddy yield. This is because the attribute which is in association do not exist by themselves, but are linked to other components. The path coefficient analysis suggested by Dewey and Lu (1959) specified the effective measure of direct and indirect causes of association and also depicts the relative importance of each factor involved in contributing to yield.

\section{REFERENCES}

Dewey, DR; Lu, KH (1959). A correlation and path coefficient analysis of components of crested wheat grass and seed production. Agronomy J. 51: 515-517

FAOSTAT (2018). Food and agricultural organization of the United States. http://faostat.fao.org/site/567/default. Date retrieved, 14th September, 2019.

Foley, JA; Ramankutty, N; Brauman, KA; Cassidy, ES; Gerber, JS; Johnston, M (2011). Solutions for a cultivated planet. Nature 478, 337-342

Iqbal, M; Chang, MA; Iqbal, MZ; Hassan, M (2003). Correlation and path coefficient analysis of earliness and agronomic characters of upland cotton in Multan. J. Agronomy, 2(3). 160-168
JAYASUDHA, S; SHARMA A (2010). Genetic parameters of variability, correlation and path coefficient for grain yield and physiological traits in rice (Oryza sativa L.) under shallow lowland situation. Elec. J. Plant Breeding, 1(5): 13321338

Qian, Q; Guo, LB; Smith, SM; Li, JY (2016). Breeding high-yield superior quality hybrid super rice by rational design. Natl. Sci. Rev.3. 283-294

Ray, DK; Ramankutty, N; Mueller, ND; West, PC; Foley, JA (2012). Recent patterns of crop yield growth and stagnation. Nat. Commun. 3:1293

Singh SK; Bhati PK; Sharma A; Sahu V (2015). Super hybrid rice in China and India: current status and future prospects. Int J Agric and Biol 17: 221-232.

Venu, R; Sreerekha, M; Nobuta, K; Belo, A; Ning, Y; An, G (2011). Deep sequencing reveals the complex and coordinated transcriptional regulation of genes related to grain quality in rice cultivars. BMC Genomics 12:190. Doi:10.1186/1471-2164-12-190

Zeng, D; Tian, Z; Rao, Y; Dong, G; Yang, Y; Huang, L (2017). Rational design of high-yield and superior-quality rice. Nat. Plants 3:17031

Zulqarnain H; Abdussalam K; Samta, Z (2012). Correlation and path coefficient analysis of yield components in rice (Oryza sativa L.) under simulated drought stress condition. AmericanEurasian J. Agric. Environ. Sci. 12 (1): 100-104 